\title{
A missão da Igreja em tempos de pandemia
}

\section{The Church's mission in times of pandemic}

\author{
Tiago de Fraga Gomes* \\ PUC-RS
}

Recebido em: 14/06/2021. Aceito em: 16/06/2021.

Resumo: A lgreja precisa se renovar e adaptar constantemente, em atitude de aggiornamento, a fim de ser fiel à sua vocação e missão, especialmente em tempos difíceis, como é o caso da pandemia, vivenciada atualmente por toda a humanidade. Para buscar essa atualização, alguns critérios pastorais a partir da missão de Cristo, do caminho até o Reinado de Deus, da presença e missão no mundo e da figura exemplar de Maria, ajudam a Igreja a amadurecer sua autoconsciência e atividade pastoral. O presente artigo visa elaborar apontamentos para que a missão da Igreja seja um sinal de esperança nesses tempos de crise pandêmica.

Palavras-chave: Igreja. Ação Pastoral. Missão. Pandemia. Esperança.

Abstract: The Church needs to constantly renew and adapt, in an attitude of aggiornamento, in order to be faithful to its vocation and mission, especially in difficult times, such as the pandemic, currently experienced by all humanity. In order to seek this update, some pastoral criteria based on the mission of Christ, the path to the Reign of God, the presence and mission in the world and the exemplary figure of Mary, help the Church to mature in her self-awareness and pastoral activity. This article aims to draw up notes so that the Church's mission can be a sign of hope in these times of pandemic crisis.

Keywords: Church. Pastoral Action. Mission. Pandemic. Hope.

* Doutor em Teologia, Pontifícia Universidade Católica do Rio Grande do Sul, PUC-RS, Porto Alegres, RS, com estágio pela Ruhr-Universität Bochum, Alemanha (2020); Mestre em Teologia, Pontifícia Universidade Católica do Rio Grande do Sul - PUC-RS, Porto Alegre, RS (2015); Bacharel em Teologia, Pontifícia Universidade Católica do Rio Grande do Sul - PUC-RS e Pontificia Università Lateranense, Itália (2012); Bacharel em Filosofia pela Pontifícia Universidade Católica do Rio Grande do Sul (2007); Professor do Programa de Pós-Graduação em Teologia da Pontifícia Universidade Católica do Rio Grande do Sul - PUC-RS.

E-mail: tiago_mail@yahoo.com.br. 


\section{Introdução}

O aggiornamento proposto à Igreja pelo Concílio Vaticano II é um desafio constante, especialmente em tempos de pandemia. Como afirma Souza, "a transformação tende a adaptar a Igreja aos tempos atuais." $\mathrm{O}$ velho axioma Ecclesia semper reformanda traz uma ideia sempre atual de que a Igreja é uma realidade em contínua renovação e adaptação para que possa corresponder com fidelidade à sua vocação e missão de ser um sacramento de Deus no mundo, sempre atenta aos sinais dos tempos, em atitude de abertura às novas interpelações da realidade humana e social.

\section{Uma Igreja que se renova e se adapta a partir de alguns critérios pastorais}

A pandemia trouxe inúmeras questões que merecem reflexão: distanciamento social, problemas sanitários, intensificação de angústias existenciais, novas formas de engajamento na comunidade, reafirmação da necessidade de conectar fé e vida diante de situações difíceis, novas formas de expressar a fé pelas redes sociais, etc. A seguir, elege-se alguns critérios para a renovação e adaptação da Igreja em tempos de pandemia, tendo em vista alguns aspectos referenciais que brotam da missão de Cristo, do caminho até o Reinado de Deus, da presença e missão no mundo e da figura exemplar de Maria.

\subsection{Critérios que brotam da continuidade da missão de Cristo}

Critério teândrico: A Igreja continua a missão de Cristo no mundo; a partir do mistério da encarnação, constitui-se como estrutura teândrica, humano-divina, que se conjuga na ação pastoral. Como em Cristo, a acentuação unilateral de uma das naturezas da Igreja produz heresias, originando desvios pastorais como o quietismo pastoral enquanto acentuação no trabalho pastoral da ação divina em detrimento da humana por uma má compreensão da eficácia da graça sacramental, independente da ação realizada pelo ministro ou agente de pastoral - maximização do axioma ex opere operato -, transferida à pastoral como um todo; ou

1 SOUZA, Luiz Gómez de. Do Vaticano Il a um novo Concílio? O olhar de um cristão leigo sobre a Igreja. São Paulo: Loyola; Goiás: Rede Paz, 2004. p. 246-247. 
mesmo um certo naturalismo pastoral como ênfase, na ação pastoral, da ação humana - neopelagianismo pastoral (EG 94) -, compreendendo a instituição e a ação eclesial como produtos da iniciativa e de interesses puramente humanos, reduzindo, assim, a Igreja, a uma simples organização social. Contudo, é preciso frisar que a missão eclesial continua no mundo a missão de Cristo pelo caminho da encarnação. Deus realiza seus planos a partir da colaboração humana. Por não ser simplesmente o produto de forças humanas, a Igreja precisa ter clareza de que é a graça de Deus que a edifica, sendo a ação pastoral o lugar do protagonismo divino e humano. Isso reforça que: na ação pastoral deve estar presente a atitude de fé, confiança e esperança em Deus que continua agindo na Igreja; não é possível manipular Deus, mas deixar Deus ocupar seu papel na ação pastoral, a qual visa conduzir ao encontro do ser humano e do mundo com Deus; é necessário avaliar a ação pastoral em relação à ação e à revelação de Deus, considerando-a como o lugar da colaboração humana com o projeto de Deus, através de um trabalho sério, honesto e responsável. ${ }^{2}$

A Igreja é uma realidade humana e divina, imanente e transcendente. ${ }^{3}$ A unidade entre o mistério da Igreja e o povo de Deus, supera uma visão fechada e estática da Igreja, fazendo aparecer seu caráter dinâmico, como povo de Deus em marcha, em perspectiva escatológica. ${ }^{4}$ A Igreja é um mistério, vem de Deus, é Ekklesía tou Theou, e está a serviço de seu desígnio de salvação. A Igreja é mediadora das graças salvíficas de Deus para a humanidade, sua organização temporal, tem como meta a dimensão sobrenatural da graça. A Igreja existe a partir de Deus e em Deus; não existe por si mesma, mas é um instrumento de Deus ${ }^{5}$, a fim de que "Deus seja tudo em todos" (1Cor 15,28); por isso, é misteriosamente um organismo de salvação. ${ }^{6}$ Contudo, o caráter teândrico da Igreja se

Cf. RAMOS GUERREIRA, Julio A. Teología Pastoral. Madrid: BAC, 1995. p. 102-104.

3 Cf. KLOPPENBURG, Boaventura. A eclesiologia do Vaticano II. Petrópolis: Vozes, 1971. p. 92.

4 Cf. HACKMANN, Geraldo Luiz Borges. A amada Igreja de Jesus Cristo: manual de eclesiologia como comunhão orgânica. Porto Alegre: Edipucrs, 2003. p. 54.

5 Cf. HACKMANN, Geraldo Luiz Borges. A Igreja da Lumen Gentium e a Igreja da Gaudium et Spes. Teocomunicação, Porto Alegre, v. 35, n. 150, p. 621-867, Dez. 2005a, p. 663.

6 Cf. HACKMANN, Geraldo Luiz Borges. A Igreja, mistério de comunhão e as exigências da evangelização do mundo. Teocomunicação, Porto Alegre, v. 35, n. 147, p. 1-176, Mar. 2005b, p. 15. 
constitui em fonte permanente de tensão. ${ }^{7} \mathrm{O}$ mistério da Igreja pode se caracterizar como mysterium lunae: a Igreja resplandece a luz de Cristo, o sol de justiça, única fonte de luz e salvação; a Igreja é como a lua, de Cristo recebe toda a luz; a Igreja é luz reflexa que mostra o caminho da salvação; no seu itinerário histórico, enfrenta as vicissitudes humanas, passando por diferentes fases de seu resplendor.

Critério sacramental: A Igreja, sacramento de salvação, realiza sua ação pastoral de forma sacramental, continuando no mundo a mediação sacramental do próprio Cristo. A Igreja é o corpo de Cristo; "nós, embora muitos, somos um só corpo" (1Cor 10,17); "somos muitos e formamos um só corpo em Cristo, sendo membros uns dos outros" (Rm 12,5); assim como em um corpo há diversos membros com funções específicas e diversas, do mesmo modo acontece na Igreja: cada um é um membro peculiar dotado de carismas específicos que o Espírito dotou para a edificação de todos os membros; "na edificação do corpo de Cristo há diversidade de membros e de funções" (LG 7), mas único é o Espírito que dá dinamicidade e coesão ao corpo todo; este corpo não é acéfalo, Cristo está na cabeça e no corpo (SCar 36). A estrutura sacramental relaciona-se à analogia do Verbo encarnado e é possível graças a ação do Espírito. Quando se fala em sacramento, refere-se ao sinal e à eficácia, os quais têm uma relação direta com a ação pastoral: a ação pastoral está a serviço do mistério da Igreja, da comunhão de Deus com os homens e dos homens entre si, sendo esta a prioridade da ação pastoral, a qual tem um elemento externo, visível, necessário na dinâmica sacramental, como caminho imprescindível para a comunhão interna; toda estrutura e ação pastoral é simbólica, refere-se a algo além do sensível, que transcende a visibilidade para tornar a invisibilidade presente e operar a salvação escatológica no interior da história; toda ação pastoral se caracteriza por sua eficácia, pois não apenas significa a salvação, mas a torna presente e operante, além disso, a ação pastoral não é alheia à edificação da história, mas se empenha para que a mesma se abra à salvação. Sendo assim, é preciso afirmar que a ação da Igreja: não pode desligar-se da instituição visível, reduzindo-se a um espiritualismo desencarnado; não deve favorecer a instituição pela instituição, deixando de lado o que por ela significa; de forma alguma pode ignorar os significados e os significantes humanos - conteúdos e formas de expressão; não pode encerrar-se nos níveis intraeclesiais, sem abertura ao mundo e

7 Cf. HACKMANN, 2003, p. 148. 
ao eschaton. ${ }^{8}$ A aplicação à Igreja da categoria de sacramento feita pelo Concílio Vaticano II é um meio conceitual para superar o juridicismo eclesiológico e destacar o mistério da Igreja, captável apenas na fé, além de explicitar a natureza e a vocação da Igreja que vem de Deus e é seu sinal e instrumento no mundo. ${ }^{9} \mathrm{O}$ conceito de sacramento exprime a dupla dimensão da Igreja, humana e divina, visível e invisível, sendo o visível, uma mediação do invisível. ${ }^{10}$

Critério de conversão: A ação pastoral da Igreja comporta contingência e pecado, ocorre entre a graça de Deus, que a edifica, e o pecado da infidelidade humana. Por isso, há necessidade de conversão. É preciso cuidar sobre duas posições errôneas: o triunfalismo, que identifica diretamente todas as ações da Igreja com a autoria divina, e o secularismo, que não reconhece a assistência do Espírito Santo para a eficácia das ações sacramentais e dogmáticas da Igreja, identificando-as com uma autoria puramente humana. Por isso, é necessária uma compreensão realista da ação pastoral, não limitada à eficácia ex opere operantis, a fim de reafirmar a mediação de Cristo e a fidelidade de Deus, apesar da infidelidade humana. A Igreja, na sua distinção com Cristo, reconhece certa distância que a separa do seu Senhor; a purificação e a conversão são critérios da ação pastoral da Igreja que enfatizam o quanto as reformas na Igreja são necessárias. ${ }^{11}$

\subsection{Critérios que brotam do caminho até o Reinado de Deus}

Critério de historicidade: Assim como Cristo, a Igreja está situada em uma história de salvação na qual Deus realiza sua ação na mediação dos acontecimentos históricos. Inaugurada na plenitude dos tempos, a Igreja vive uma história marcada pela escatologia - já e ainda-não-em que a plenitude já está presente, mas ainda não se manifestou plenamente. A Igreja, povo de Deus peregrino, que participa nos acontecimentos da humanidade ${ }^{12}$, traz como marca de toda sua ação pastoral, o dinamismo

\footnotetext{
8 Cf. RAMOS GUERREIRA, 1995, p. 104-107.

9 Cf. PIÉ-NINOT, Salvador. Eclesiología: la sacramentalidad de la comunidad cristiana. Salamanca: Sígueme, 2007. p. 206.

10 Cf. PIÉ-NINOT, Salvador. Introdução à eclesiologia. 5. ed. Trad. João Paixão Netto. São Paulo: Loyola, 2010. p. 30.

11 Cf. RAMOS GUERREIRA, 1995, p. 107-109.

12 Cf. COMBLIN, José. O povo de Deus. São Paulo: Paulus, 2002. p. 33-34.
} 
da história, em uma tensão entre a Igreja e o Reinado de Deus, que se manifesta pelas seguintes questões: a Igreja não se instala em um momento da história sentindo-se no acabamento do Reinado de Deus; a Igreja reconhece Deus em sua própria história e supera dificuldades internas e externas com a força do Ressuscitado. Sendo assim, a Igreja atua na história, e isso se reflete: nas ações e estruturas que respondem às necessidades históricas da evangelização; no acompanhamento das pessoas em suas diferentes etapas, respeitando seu amadurecimento progressivo, em um horizonte comunitário; na renovação pastoral marcada pela situação do momento e pelo ideal buscado. Nesse sentido, uma pastoral de conservação pode ser considerada como uma forma de infidelidade pastoral ao próprio ser dinâmico da Igreja. ${ }^{13}$

Critério de abertura aos sinais dos tempos: a necessidade de aggiornamento leva a Igreja a abrir-se aos sinais dos tempos, a fim de se renovar e se atualizar. ${ }^{14}$ Os valores do Reinado de Deus não estão encerrados nos limites visíveis da Igreja, mas a transcendem. O Espírito Santo desperta os valores do Reinado de Deus no seio da humanidade e do mundo, sem que a Igreja tenha direitos exclusivos sobre eles. Para que a Igreja cumpra a sua missão, é necessário que espreite os sinais dos tempos, que conheça o mundo onde vive, com suas esperanças e aspirações, que ouça através da sua vida, a voz de Deus que aponta os caminhos da missão. Examinar os sinais dos tempos implica: uma leitura da realidade a partir da fé, passando da simples materialidade das coisas, ao seu sentido e significado profundo para a vida e para o ser humano; um confronto da realidade com o Evangelho para discernir o que é sinal do Reinado de Deus e deve ser promovido, e o que é anti-Reinado e precisa ser liberto na ação pastoral; descobrir na realidade quais são as questões profundas do ser humano e que respostas este espera em relação ao sentido da vida, presente e futura; discernir o chamado de Deus a partir da realidade para que a ação pastoral contribua para a ação salvífica de Cristo. O conhecimento da situação, como fonte da ação pastoral, vai além do aspecto fenomenológico - confronto da realidade com o Evangelho -, com o intuito de descobrir novos caminhos para a ação pastoral. Para isso, é necessária uma atitude de abertura que rompe a intraeclesialidade e penetra na vida humana, e uma avaliação do mundo como lugar da incipiente presença do Reinado de Deus que

13 Cf. RAMOS GUERREIRA, 1995, p. 109-111.

14 Cf. ALBERIGO, Giuseppe. Transizione epocale: studi sul Concilio Vaticano II. Bologna: Società editrice il Molino, 2009. p. 42. 
precisa ser explicitada e tornada consciente às pessoas. Escrutinar os sinais dos tempos com discernimento pastoral implica: uma postura crítica em relação às ideias, ideologias e ações comuns da humanidade, pois a Igreja não pode ignorar o que move o ser humano - pois, não há nada verdadeiramente humano que não encontre eco em seu coração (GS 1); uma doutrina esclarecedora sobre o sentido da realidade e as opções de significado que devem estar subjacentes a qualquer compromisso de ação - ideal de vida; um compromisso concreto com a realidade - pístis e práxis; uma postura crítica em relação às próprias opções, confrontando-as com o Evangelho. ${ }^{15}$

Critério de universalidade: A universalidade da salvação é imperativo e critério para a ação da Igreja que, graças ao Espírito, atualiza e universaliza o mistério de Cristo a toda humanidade. Assim como a salvação de Cristo é universal, a Igreja deve ter a capacidade de se encarnar nas diferentes culturas. Essa salvação está ligada à sua comunidade. Portanto, o convite à salvação passa pelo convite a integrar a comunidade eclesial. A entrada e participação nessa comunidade precisa ser favorecida a todos. Este universalismo da missão eclesial deve ser compreendido tanto quantitativamente - salvação para todos -, quanto qualitativamente - todos os membros da Igreja são agentes da sua ação pastoral. A respeito disso, é necessária uma atenção à duas tentações: contra o universalismo quantitativo há o ecletismo que foge a qualquer compromisso, que identifica o universalismo com a ausência de critérios ou falta de crítica para a evangelização; contra o universalismo qualitativo há as metodologias pastorais autorreferenciais, que restringem a eclesialidade a um determinado grupo de pessoas. Nesse sentido, por ser universal, a Igreja é missionária. Uma comunidade que não sente as necessidades da missão, está vocacionalmente estagnada. ${ }^{16}$

\subsection{Critérios que brotam da presença e missão no mundo}

Critério do diálogo: Com o Concílio Vaticano II, a Igreja sai de uma estrutura de defesa e entra em uma estrutura de diálogo. ${ }^{17}$ A Igreja aprofunda a consciência de que sua missão não se esgota em seus aspectos ad intra, mas tem o mundo como destinatário. A Igreja está a serviço da

\footnotetext{
15 Cf. RAMOS GUERREIRA, 1995, p. 111-113.

16 Cf. RAMOS GUERREIRA, 1995, p. 113-115.

17 Cf. SOUZA, 2004, p. 246-247.
} 
revelação de Deus através da pastoral da Palavra, em atitude dialógica. A ação pastoral dirige-se ao mundo para atualizar a Palavra que se fez carne para a salvação de todos. A revelação de Deus é o paradigma do diálogo eclesial a serviço do mundo: a revelação é dom que nasce da iniciativa divina, por isso, a palavra eclesial é tarefa e missão; a revelação vem do amor, nesse sentido, a Igreja é missionária amando; a revelação não condiz com os méritos dos receptores, sendo assim, a Igreja dialoga com o mundo a partir da gratuidade, e sua ação, não é troca comercial, mas recebe e dá de-graça; a revelação é proposta, não imposta, portanto, a Igreja, longe de todo fanatismo, faz da sua missão uma proposta livre, à serviço da salvação, sem forçar consciências e decisões; a revelação é para todos, em virtude disso, a Igreja universaliza a Palavra no tempo e no espaço; a revelação é progressiva, logo, a Igreja acompanha o ser humano e o mundo respeitando seu amadurecimento e progressão histórica. Todas essas questões apontam para o fato de que o diálogo entre a Igreja e o mundo requer algumas atitudes fundamentais: para a identidade da ação eclesial, pois a Igreja dialoga e faz propostas ao mundo a partir de sua referência identitária a Cristo e ao Reinado de Deus; para a abertura aos sinais dos tempos, pois a Igreja dialoga comunicando e ouvindo; para o diálogo dentro da própria Igreja, pois a missão parte e conduz à comunhão. ${ }^{18}$

Critério da encarnação: O critério sacramental trata da necessidade do visível, do humano e do estrutural na vida da Igreja para torná-la um instrumento a serviço da salvação. O critério da encarnação enraíza-se no mistério da encarnação. A encarnação de Cristo e o prolongamento pneumático no mistério da Igreja implicam na inculturação, que exige da Igreja adaptação às mudanças culturais. ${ }^{19}$ Para que a mensagem de Cristo e sua missão entrem em contato dialógico com o mundo, é necessário que se encarnem em suas próprias dimensões culturais. Do contrário, o Evangelho nunca será assimilado pelas pessoas e pelos povos, e a estrutura sacramental da Igreja nunca será significativa. Os dois eventos fundadores da Igreja manifestam como Deus age assumindo moldes culturais: na encarnação, o Filho de Deus assume uma cultura concreta com linguagem, tradições, modo de vida, esperanças; em Pentecostes, o mistério pascal de Cristo penetra nas diferentes culturas, as quais encontram nele a resposta às suas questões existenciais. O Evangelho

18 Cf. RAMOS GUERREIRA, 1995, p. 115-117.

19 Cf. SUESS, Paulo. O processo da inculturação. In: PINHEIRO, Ernanne (coord.). Santo Domingo: uma leitura pastoral. São Paulo: Paulinas, 1993. p. 53. 
é anunciado na ação pastoral da Igreja graças à mediação cultural e, ao mesmo tempo, sua ação cria cultura, modos de vida. Talvez o drama atual seja não saber passar da cultura como meio - patrimônio cultural como esfera vital - para a cultura como produção - criatividade, novidade. Ainda dentro desse critério, é preciso afirmar que há uma íntima relação entre evangelização e promoção humana: "a tarefa da evangelização implica e exige uma promoção integral de cada ser humano" (EG 182). Sendo assim, a acolhida dos últimos e dos pobres é sinal evangélico de autenticidade e credibilidade da ação evangelizadora. Em Lc 4,18-19, a evangelização dos pobres é sinal da chegada do Reinado de Deus. ${ }^{20}$

Critério de missão: Com a recepção do Espírito Santo, a Igreja foi enviada para continuar a fazer o que Jesus fez na história. Esta missão é a evangelização de todos as pessoas: esta é a base da identidade de toda a ação pastoral da Igreja. Todos os fiéis participam desta missão, cada um a partir de seus dons e ministérios. Duas posições impedem que esta missão aconteça: perda da identidade por falta de consciência da evangelização, fruto da falta de comunhão entre os membros da Igreja; uniformidade que anula a unidade da missão e a pluralidade de identidades e ministérios na Igreja, que surge do medo de mudar e da desconfiança em relação à ação do Espírito Santo na Igreja. Do cristocentrismo eclesial surgem algumas exigências para a missão da Igreja: reavaliar o conceito de missão, de uma promoção de aspectos intraeclesiais, construída em um mundo sociologicamente cristão, para uma ação pastoral em saída para um mundo cada vez mais secularizado - a missão deve ser o critério fundamental de toda ação pastoral; reavivar a consciência da missão, como fundamento da Igreja e necessidade para todos os seus membros; necessidade de uma pastoral de conjunto que combine unidade e pluralidade em torno da missão, superando toda desintegração pastoral; organização da ação pastoral baseada no pluralismo de dons e carismas; a missão da Igreja não esgota a missão de Cristo no mundo, está a seu serviço e orienta-se para a comunhão. ${ }^{21}$

\subsection{Critérios que brotam da figura exemplar de Maria}

Maria, imagem da Igreja: A exemplo de Maria, a Igreja é chamada à perfeição e à santidade para ser sinal de Deus no mundo. A figura

20 Cf. RAMOS GUERREIRA, 1995, p. 117-119.

21 Cf. RAMOS GUERREIRA, 1995, p. 119-121. 
de Maria é um modelo fiel do discipulado e da comunhão com o plano salvífico de Deus. À imagem de Maria, a Igreja é mãe e peregrina na história, com uma dimensão escatológica; Maria é a Igreja já realizada ou aquilo que a Igreja será quando terminar seu percurso na terra. ${ }^{22}$ Maria é tipo e modelo da Igreja. Em Maria, a Igreja contempla o seu modelo mais perfeito. Maria é o protótipo e o símbolo da plenitude da Igreja, "já glorificada no céu em corpo e alma, é imagem e primícia da Igreja", é "sinal de esperança segura e de consolação, aos olhos do povo de Deus peregrinante" (LG 68). É a figura-tipo da Igreja-mãe que gera filhos para Deus. É a mãe carnal de Jesus e a mãe espiritual dos discípulos. Maria é a mãe da Igreja, da comunidade de fé; é a mãe dos crentes. Assim, afirma-se que Maria gerou a Cristo na carne, e a Igreja, gera a Cristo nos corações.

Maria, discípula perfeita de Cristo: Sua vida tem um valor exemplar para a vida de cada cristão; Maria aderiu total e responsavelmente à vontade de Deus, nas condições concretas de sua vida; "Maria não foi instrumento meramente passivo nas mãos de Deus, mas cooperou na salvação dos homens com fé livre e com inteira obediência" (LG 56); soube acolher a Palavra e colocá-la em prática. Maria "refulge diante de toda a comunidade dos eleitos como modelo de virtudes" (LG 65). Pela desobediência e incredulidade de Eva, a morte entrou no mundo; pela obediência e fé de Maria, entrou a vida.

Maria, toda cristocentrada: Todo mistério mariano é cristocêntrico. "As funções e os privilégios da bem-aventurada Virgem, sempre se referem a Cristo, origem de toda a verdade, santidade e devoção" (LG 67). A maternidade divina é o acontecimento central e a orientação fundamental de toda a vida de Maria. Maria é toda relativa a Cristo e, a partir de Cristo, relativa à Igreja. Como a crente por excelência, representa a comunidade eclesial, a humanidade salva por Cristo.

\section{Uma Igreja que busca ser sinal de deus no mundo e na vida das pessoas}

À luz dos critérios expostos, percebe-se que a Igreja existe no mundo para testemunhar o desígnio salvífico de Deus, em uma tensão entre o humano e o divino, entre o histórico e o escatológico, entre o

22 Cf. HACKMANN, 2005a, p. 667. 
já e o ainda-não, entre a memória do que foi e a esperança daquilo que virá, tendo em vista as situações do momento, aquilo que toca o coração das pessoas, em cada contexto e lugar. O contexto atual de pandemia faz pensar sobre muitas questões que põem em xeque a vivência cristã dos valores Evangelho em comunidade. O distanciamento social é um imperativo sanitário, contudo, leva a pensar em alternativas para não deixar morrer o sentido de pertença à comunidade eclesial e à missão cristã no mundo. Como na Sagrada Escritura a Aliança e a Promessa de Deus impulsionam a caminhada do povo de Deus, da mesma forma, continuam a sustentar a ação evangelizadora e o testemunho da Igreja em meio às intempéries e agitações pelas quais passam atualmente os discípulos de Cristo e toda a humanidade. Diante da intensificação de angústias existenciais, é preciso pensar novas formas de acompanhamento personalizado; diante de um arrefecimento do sentido de participação - fala-se em "assistir" às celebrações, e não "participar" -, é necessário fomentar novas maneiras de engajamento das pessoas nas atividades litúrgicas e pastorais, com sentido de pertença à comunidade, tendo em vista o ser eclesial encarnado no cotidiano. ${ }^{23}$

Ser Igreja é buscar conciliar na própria vida a ortodoxia e a ortopráxis evangélica. Mais do que mestres e bons oradores, o mundo precisa de testemunhos concretos da dinâmica do Reino de Deus, que, segundo o Papa Pio XII, transformem o mundo de selvagem em humano e de humano em divino, segundo o coração de Deus. Os mais atentos percebem na atual situação do mundo uma profunda crise espiritual, provocada pela ausência de referências sólidas e de correspondentes convicções, requeridas para tornar reais os valores que tragam vida, justiça e felicidade para a humanidade. A pandemia impõe a necessidade de reconectar fé e vida de maneira consistente. Em tempos dificeis, subsiste aquilo que tem consistência. Urge superar representações arcaicas e anacrônicas da fé, desprovidas de comprometimento com os valores do Reino de Deus. Como afirma o Documento de Aparecida, é necessário "abandonar as ultrapassadas estruturas que já não favorecem a transmissão da fé" (DAp 365), através de uma conversão pessoal de cada um dos membros da Igreja, com seus correspondentes ministérios, e de uma conversão pastoral, com o intuito de assumir a dinâmica da Ecclesia semper reformanda, aberta aos apelos atuais da missão evangelizadora.

23 MIRANDA, Mario de França. A lgreja que somos nós. São Paulo: Paulinas, 2013. p. 14. 
Segundo a Lumen Gentium, o Espírito Santo santifica, habita, guia, unifica e rejuvenesce a Igreja (LG 4), sustentando-a em sua peregrinação histórica e contextual, entre as adversidades do mundo e as consolações de Deus (LG 8). A Igreja, em sua dimensão teândrica, tem como princípio o amor ao próximo (Jo 13,34-35) e como finalidade o Reinado de Deus (LG 9); em sua dimensão sacramental, tem como objetivo ser um sinal concreto e eficaz da ação divina no mundo. Assim como a encarnação do Verbo de Deus estava voltada para a salvação da humanidade, assim também a Igreja de Cristo só se justifica enquanto está a serviço dessa salvação ao longo da história humana. Toda a vida de Jesus com sua paixão, morte e ressurreição esteve a serviço do Reinado de Deus; do mesmo modo, tudo o que constitui a Igreja alcança sua razão e sentido de ser na medida em que leva a mensagem evangélica e a práxis cristã aos seus contemporâneos. A Igreja é, desse modo, uma realidade não voltada para si, mas para a sociedade na qual deve ser sal, luz e fermento. ${ }^{24} \mathrm{Na}$ Gaudium et Spes fica claro como as situações existenciais da humanidade ecoam no coração da Igreja: "As alegrias e as esperanças, as tristezas e as angústias dos homens de hoje, sobretudo dos pobres e de todos aqueles que sofrem, são também as alegrias e as esperanças, as tristezas e as angústias dos discípulos de Cristo" (GS 1). Trata-se "de salvar a pessoa humana e de restaurar a sociedade" (GS 3), sem descuidar dos "sinais dos tempos" (GS 4), a fim de compreender as profundas transformações vivenciadas pela humanidade, para evangelizar com eficácia.

Como afirma o Papa Francisco na Evangelii Gaudium, a Igreja é convidada, na "dinâmica do dom e do êxodo" (EG 21), a sair de si mesma, a ir ao encontro, com o intuito de alcançar os mais necessitados nas periferias existenciais, pois, como afirma Miranda, "numa época carente de referências sólidas, o testemunho pessoal e comunitário adquire um valor excepcional na evangelização." ${ }^{25}$ Para isso, é preciso que a Igreja se preocupe menos com burocracias pastorais e administrativas, e mais com relações verdadeiramente humanas e fraternas. Isso implica em inserir-se na extremamente complexa, fragmentada e diversificada da sociedade atual, evitando generalizações apressadas, disposta a ler realidade a partir da fé, em incidir sobre ela com ardor apostólico. A fé testemunhada traz o Deus vivo ao mundo. Segundo Miranda, "o cristão autêntico irradia

24 MIRANDA, 2013, p. 45.

25 MIRANDA, 2013, p. 128. 
Deus para seus contemporâneos." ${ }^{26}$ Transmitir a fé, mais do que entregar um pacote de verdades a outras pessoas, significa transmitir uma experiência salvífica determinante e decisiva do próprio Deus vivo. Por isso, é possível afirmar que a fé é uma convicção encarnada que desencadeia processos. $\mathrm{O}$ autêntico testemunho cristão precisa vir acompanhado das razões da própria esperança (1Pd 3,15). O ato pessoal de fé (fides qua) não pode prescindir de seu conteúdo (fides quae), e vice-versa, a fim de que o mesmo seja uma ação consciente e consistente, e além disso, possa servir de referência axiológica para outras pessoas.

Ser sinal do Reinado de Deus em um mundo em pandemia é uma grande missão para a Igreja atual; implica em um exercício de fé e de decidida conversão ao Evangelho (Mc 1,15), numa atitude de confronto com a pessoa de Cristo no hoje da história. Uma fé viva acarreta em repercussões na sociedade. O mundo marcado pelas estruturas de pecado e pelo egoísmo reage muitas vezes por interesses comerciais e desumanos; nessa pandemia, ficou claro como a preocupação com a "economia", em muitos momentos, se sobrepôs à salvaguarda da vida do próprio ser humano. Diante disso, a Igreja precisa se engajar com a causa de Deus, que é o ser humano vivo! Para isso, é preciso ter firmeza e ousadia parresia -, pois a mensagem do Reinado de Deus incentiva os cristãos a se empenharem por uma sociedade mais sensível aos sofrimentos das pessoas, desvelando a idolatria do mercado. ${ }^{27}$ Os símbolos cristãos $-\mathrm{Pa}-$ lavra de Deus, Símbolo da Fé, celebrações litúrgicas - passam atualmente por um deficit de significado, exigindo um esforço inédito por parte da Igreja para continuarem a motivar as pessoas ao protagonismo da fé em favor da vida. ${ }^{28}$

\section{Conclusão}

A pandemia do coronavírus realçou a fragilidade humana, invocou nas consciências o medo da morte ${ }^{29} \mathrm{e}$ colocou a humanidade em estado de

\footnotetext{
MIRANDA, 2013, p. 187.

27 MIRANDA, 2013, p. 259.

28 Cf. KASPER, Walter. A Igreja católica: essência, realidade, missão. Trad. Nélio Schneider. São Leopoldo: Unisinos, 2012. p. 125-126.

29 Cf. CANABARRO, Ivo dos Santos; STRÜCKER, Bianca; HAHN, Noli Bernardo. A história do medo revisitada: ética da alteridade frente à covid-19 como uma pandemia do século XXI. Estudos Teológicos, São Leopoldo, v. 60, n. 2, p. 404-417, Maio/Ago. 2020, p. 405.
} 
crise: sem conhecer a causa e a origem dessa adversidade, todos os seres humanos se veem ameaçados em sua sobrevivência. A multiplicação de mortes revela que ninguém está livre de um fim trágico. ${ }^{30}$ São momentos de extrema aflição que causam medo e pânico e que questionam as certezas morais e religiosas em sua radicalidade, pois é a própria vida que está em risco. ${ }^{31}$ As restrições de convivência social afetaram diretamente na forma de viver a fé cristã. Nesses tempos de crise, a Igreja não tem certeza sobre a melhor forma de como acompanhar pastoralmente as pessoas, a fim de ser um sinal de consolação e de esperança. Nesse contexto, as mídias digitais têm se firmado como um recurso fundamental para a ação evangelizadora a nível litúrgico, pastoral e catequético. Por um lado, as plataformas digitais se configuram como um modo da Igreja se conectar e sustentar a fé e a esperança das pessoas; além disso, incentivam a uma revisão de linguagem e maior objetividade e contextualização na comunicação do Evangelho; por outro lado, percebe-se alguns desvios pastorais que levam a questionar se de fato o intuito de certas manifestações no ciberespaço geram efetivamente comunhão e engajamento concreto na fé ${ }^{32}$, além de manifestar certo clericalismo e sacramentalismo. Tendo em vista que o ciberespaço integra um novo contexto existencial, como a Igreja pode, não só utilizar bem, mas viver bem, dentro dessa nova ambiência comunicativa? ${ }^{33}$

Como ocorreu no séc. III, durante o tempo da "praga de Cipriano" - provavelmente sarampo ou varíola -, em que Cipriano, bispo de Cartago, na obra De mortalitate, encoraja e exorta os cristãos a se manterem firmes na fé durante a terrível pandemia ${ }^{34}$, esse tempo de crise que se vive atualmente, faz pensar, confronta a fé e provoca a ponderar sobre o valor da vida, escancarando as prioridades pessoais e sociais, além de denunciar a lógica perversa de um sistema econômico predatório e

30 Cf. GRENZER, Matthias. Peste e pandemia: configuração poética e reflexão teológica no Salmo 91. Estudos Teológicos, São Leopoldo, v. 60, n. 2, p. 433-445, Maio/Ago. 2020, p. 434.

31 Cf. WOLFF, Elias. Igreja católica e fé cristã em tempos de coronavírus/COVID-19. Estudos Teológicos, São Leopoldo, v. 60, n. 2, p. 627-648, Maio/Ago. 2020, p. 628.

32 Cf. WOLFF, 2020, p. 631-633.

33 Cf. OLIVEIRA RIO, Marlon Machado. "Nos vemos on-line": diferentes vozes sobre a busca por Deus no cenário pandêmico brasileiro. Estudos Teológicos, São Leopoldo, v. 60, n. 2, p. 610-626, Maio/Ago. 2020, p. 615.

34 Cf. GONÇALVES, José Mário. De Mortalitate: Cipriano de Cartago e a pandemia do terceiro século. Estudos Teológicos, São Leopoldo, v. 60, n. 2, p. 390-403, Maio/Ago. 2020, p. 391. 
desumanizador. Fala-se de um "novo normal" no pós-pandemia. O que significa isso? Será melhor ou pior? Só o tempo dirá. ${ }^{35}$ Contudo, permanece a necessidade de uma revisão de valores sobre o que realmente importa. E no meio das provações e tormentos, cabe à Igreja uma palavra de esperança, de ânimo, de apoio e de consolo diante de um estado de crise. ${ }^{36}$ Cabe também um palavra profética diante de um estilo de vida que produz vazio existencial. A ignorância funcional de grande parte do povo brasileiro serve de massa de manobra para um projeto político de dominação que tem como fonte de rendimentos a exacerbação do lucro a qualquer custo, e a mercantilização da vida humana, rompendo-se, assim, com valores humanos essenciais, e perdendo-se de vista o ministério da política em vista do bem comum. ${ }^{37}$ É preciso suscitar nos cristãos uma rede de colaboração que promova uma nova consciência da fé e atitudes práticas em favor da vida.

\section{Referências}

ALBERIGO, Giuseppe. Transizione epocale: studi sul Concilio Vaticano II. Bologna: Società editrice il Molino, 2009.

BENTO XVI, Papa. Exortação Apostólica Pós-Sinodal Sacramentum Caritatis: sobre a Eucaristia, fonte e ápice da vida e da missão da Igreja. 3. ed. São Paulo: Paulinas, 2007.

BÍBLIA. Português. A Bíblia de Jerusalém. Nova edição rev. e ampl. São Paulo: Paulus, 2002.

CANABARRO, Ivo dos Santos; STRÜCKER, Bianca; HAHN, Noli Bernardo. A história do medo revisitada: ética da alteridade frente à COVID-19 como uma pandemia do século XXI. Estudos Teológicos, São Leopoldo, v. 60, n. 2, p. 404-417, Maio/Ago. 2020.

COMBLIN, José. O povo de Deus. São Paulo: Paulus, 2002.

35 Cf. CUNHA, Carlos Alberto Motta. Esperança em tempo de pandemia: apontamentos da escatologia contemporânea no contexto da COVID-19. Estudos Teológicos, São Leopoldo, v. 60, n. 2, p. 483-498, Maio/Ago. 2020, p. 489-490.

37 Cf. GABATZ, Celso; ANGELIN, Rosângela. Ponderações críticas acerca da COVID-19: contribuições para ampliar o entendimento no contexto brasileiro. Estudos Teológicos, São Leopoldo, v. 60, n. 2, p. 466-482, Maio/Ago. 2020, p. 468. 
CONCÍLIO ECUMÊNICO VATICANO II. Constituição Dogmática Lumen Gentium: sobre a Igreja. In: COSTA, L. (org.). Documentos do Concílio Ecumênico Vaticano II (1962-1965). 4. ed. São Paulo: Paulus, 2007. p. 101-197.

CONCÍLIO ECUMÊNICO VATICANO II. Constituição Pastoral Gaudium et Spes: sobre a Igreja no mundo de hoje. In: COSTA, L. (org.). Documentos do Concílio Ecumênico Vaticano II (1962-1965). 4. ed. São Paulo: Paulus, 2007. p. 539-661.

CONSELHO EPISCOPAL LATINO-AMERICANO. Documento de Aparecida: texto conclusivo da V Conferência Geral do Episcopado Latino-Americano e do Caribe. 3. ed. Trad. Luiz Alexandre Solano Rossi. Brasília: CNBB; São Paulo: Paulus; Paulinas, 2007.

CUNHA, Carlos Alberto Motta. Esperança em tempo de pandemia: apontamentos da escatologia contemporânea no contexto da COVID-19. Estudos Teológicos, São Leopoldo, v. 60, n. 2, p. 483-498, Maio/Ago. 2020.

FRANCISCO, Papa. Exortação Apostólica Evangelii Gaudium: sobre o anúncio do Evangelho no mundo atual. São Paulo: Paulinas, 2013.

GABATZ, Celso; ANGELIN, Rosângela. Ponderações críticas acerca da COVID-19: contribuições para ampliar o entendimento no contexto brasileiro. Estudos Teológicos, São Leopoldo, v. 60, n. 2, p. 466-482, Maio/Ago. 2020.

GONÇALVES, José Mário. De Mortalitate: Cipriano de Cartago e a pandemia do terceiro século. Estudos Teológicos, São Leopoldo, v. 60, n. 2, p. 390-403, Maio/Ago. 2020.

GRENZER, Matthias. Peste e pandemia: configuração poética e reflexão teológica no Salmo 91. Estudos Teológicos, São Leopoldo, v. 60, n. 2, p. 433-445, Maio/Ago. 2020.

HACKMANN, Geraldo Luiz Borges. A amada Igreja de Jesus Cristo: manual de eclesiologia como comunhão orgânica. Porto Alegre: Edipucrs, 2003.

HACKMANN, Geraldo Luiz Borges. A Igreja da Lumen Gentium e a Igreja da Gaudium et Spes. Teocomunicação, Porto Alegre, v. 35, n. 150, p. 621-867, Dez. 2005a. 
HACKMANN, Geraldo Luiz Borges. A Igreja, mistério de comunhão e as exigências da evangelização do mundo. Teocomunicação, Porto Alegre, v. 35, n. 147, p. 01-176, Mar. 2005b.

KASPER, Walter. A Igreja católica: essência, realidade, missão. Trad. Nélio Schneider. São Leopoldo: Unisinos, 2012.

KLOPPENBURG, Boaventura. A eclesiologia do Vaticano II. Petrópolis: Vozes, 1971.

MIRANDA, Mario de França. A Igreja que somos nós. São Paulo: Paulinas, 2013.

RAMOS GUERREIRA, Julio A. Teología Pastoral. Madrid: BAC, 1995. OLIVEIRA RIO, Marlon Machado. "Nos vemos on-line": diferentes vozes sobre a busca por Deus no cenário pandêmico brasileiro. Estudos Teológicos, São Leopoldo, v. 60, n. 2, p. 610-626, Maio/Ago. 2020.

PIÉ-NINOT, Salvador. Eclesiología: la sacramentalidad de la comunidad cristiana. Salamanca: Sígueme, 2007.

PIÉ-NINOT, Salvador. Introdução à eclesiologia. 5. ed. Trad. João Paixão Netto. São Paulo: Loyola, 2010.

SOUZA, Luiz Gómez de. Do Vaticano II a um novo Concílio? O olhar de um cristão leigo sobre a Igreja. São Paulo: Loyola; Goiás: Rede Paz, 2004. SUESS, Paulo. O processo da inculturação. In: PINHEIRO, Ernanne (coord.). Santo Domingo: uma leitura pastoral. São Paulo: Paulinas, 1993.

WOLFF, Elias. Igreja católica e fé cristã em tempos de coronavírus/ COVID-19. Estudos Teológicos, São Leopoldo, v. 60, n. 2, p. 627-648, Maio/Ago. 2020. 